\title{
Efficacy of Pentoxifylline as an Antifibrotic Drug in Experimental Murine Schistosomal Hepatic Fibrosis
}

\author{
Eman A. Khalifa ${ }^{1}$, Heba A. Mahmoud ${ }^{2}$, Ahmad K. Farrag ${ }^{3}$, \\ Hala E. Hamouda ${ }^{4}$ and Amal A. Baalash ${ }^{4}$ \\ Departments of Parasitology ${ }^{1}$, Pharmacology ${ }^{2}$, Tropical Medicine ${ }^{3}$ and \\ Medical Biochemistry ${ }^{4}$ Faculty of Medicine-Tanta University
}

\begin{abstract}
Aim: The present study was a preliminary trial evaluating the possible antifibrotic effect of pentoxifylline on experimentally induced schistosomal hepatic fibrosis and, also, to investigate its effect on serum leptin and transforming growth factor - $\beta 1$ levels as possible antifibrotic mechanisms in correlation with the hepatic fibrosis indices. Methods: In the study, ninety Swiss, laboratory bred parasite free, albino mice of both sexes were included. Ten mice served as a control non-infected, nontreated group and sacrificed at one time. The remaining 80 mice were infected subcutaneously with 50 Schistosoma mansoni cercariae/mouse and classified into the following groups: Group I (infected \& non-treated), group II (infected \& treated with praziquantel), group III (infected \& treated with pentoxifylline) and group IV (infected \& treated with a combination of praziquantel and pentoxifylline). Each group was further subdivided into 2 subgroups; subgroup ' $a$ ' which started treatment at $6^{\text {th }}$ week post-infection (P.I.) and sacrificed at the end of $9^{\text {th }}$ week P.I and subgroup ' $b$ ' which started treatment at $14^{\text {th }}$ week $P$.I and sacrificed at the end of $17^{\text {th }}$ week P.I. The efficacy of the treatment was assessed by histopathological examination of the liver with measurement of granuloma size, estimation of hydroxyproline content in the liver, and assessment of serum levels of leptin and transforming growth factorß1 (TGF-ß1). Results: Praziquantel (PZQ) caused significant reductions in granuloma sizes and hepatic hydroxyproline content and caused non-significant reductions in serum levels of leptin and transforming growth factor- $\beta 1$ at the $9^{\text {th }} \&$ $17^{\text {th }}$ weeks P.I (group II). Pentoxifylline (PTX) caused significant reductions in granuloma size, hepatic hydroxyproline, and serum levels of leptin and transforming growth factor- $\beta 1$ at the $9^{\text {th }} \& 17^{\text {th }}$ weeks P.I (group III). Combined therapy of both PZQ \& PTX in group IV caused more reductions in granuloma size, hepatic hydroxyproline, and serum levels of leptin and TGF- $B 1$ at the 9th \& 17th weeks P.I when compared to the other groups. Conclusion: Pentoxifylline (PTX) is a promising antifibrotic drug, acting by reducing serum TGF-ß1 and leptin levels in the experimental schistosomal hepatic fibrosis. Also, the use of that antifibrotic drug in combination with antischistosomal drug, praziquantel (PZQ) was more effective in the control of fibrotic processes in schistosomal hepatic fibrosis.
\end{abstract}

\section{INTRODUCTION}

Schistosomal hepatic fibrosis is considered the major morbid sequel of
Schistosoma infection. Eggs trapped in the portal pre-sinusoidal venules induce a granulomatous inflammatory reaction with subsequent fibrosis. Fibrogenesis is a dynamic potentially 
reversible process mediated through the immunological responses to parasite eggs trapped in the liver (1). The basic pathological changes of liver fibrosis are the excessive accumulation of extra-cellular matrix (ECM) proteins. Within the major components of ECM, type I and Type II collagen constitute more than 95\% of the total content of increased collagen in liver fibrosis (1\&2). Activated hepatic stellate cells (HSCs) and portal fibroblasts have been identified as major collagenproducing cells in the injured liver. These cells are activated by fibrogenic cytokines such as leptin, transforming growth factor $ß 1$ (TGF-ß1), and angiotensin II (3). Activated HSCs migrate and accumulate at the sites of tissue repair, secreting large amounts of $\mathrm{ECM}^{(4,5, \& 6)}$.

Both CD4+ lymphocytes and kuppfer cells produce transforming growth factor $\beta 1 \quad($ TGF- $\beta 1)$ and fibrogenic mediators after contact with soluble egg antigen. Transforming growth factor ß1 (TGF$ß 1)$ is a multipotent cytokine recognized as playing an important role in regulating cell growth and development ${ }^{(7) .}$ It has been implicated as a major stimulator of tissue fibrosis by stimulating fibroblast proliferation, activation and extracellular matrix production, particularly collagen and fibronectin, and reduces their degradation $^{(8)}$. It is considered the most critical cytokine in determining the process of fibrogenesis in schistosomiasis $^{(7 \& 8)}$.

Also, it is postulated that adipocytokines, a group of cytokines produced exclusively from adipose tissue [i.e., leptin, adiponectin, resistin, plasminogen activator inhibitor (PAI)-1], play a pivotal role in the pathogenesis of liver fibrosis ${ }^{(\mathbf{9}}$ .Leptin is one of the adipokines that is expressed in adipocytes and secreted into the bloodstream in proportion to adipose tissue mass. Lines of evidence indicate that leptin is a profibrogenic cytokine in the liver ${ }^{(\mathbf{1 0})}$. Leptin is produced by hepatic stellate cells (HSCs) but only following their activation where activation of HSCs is a central event in the fibrotic response to liver injury ${ }^{(11 \& 12)}$.

Treatment with antifibrotic drugs, as an adjunct to anti-schistosomal chemotherapy, praziquantel, has been proposed as a way for preventing hepatic fibrosis and reducing its morbidity (13). Reversibility of advanced liver fibrosis in patients with schistosomiasis has been documented, these evidences have stimulated the researchers to develop seek for the best antifibrotic drugs.

Emerging antifibrotic therapies are aimed at inhibiting the accumulation of fibrogenic cells and/or preventing the deposition of extracellular matrix proteins or inhibition of the accumulation of activated HSCs by modulating either their activation and/or proliferation or promoting their apoptosis ${ }^{(14)}$. Antagonists to hepatic fibrogenesis cytokine profile may be another strategy in the treatment of hepatic fibrosis. Since hepatic fibrogenesis depends largely on fibroblast growth factors, mainly TGF- $\beta 1$, so prevention of fibrosis by anti-TGF- $\beta 1$ intervention could be therapeutically useful in treating hepatic fibrosis ${ }^{(15 \& 16)}$.

It has been documented that substances that inhibit key signal 
transduction pathways involved in liver fibrogenesis, also, have the potential to treat liver fibrosis. They include pentoxifylline (phosphodiesterase inhibitor) and amiloride $\quad(\mathrm{Na}+\mathrm{H}+\quad$ pump inhibitor ${ }^{(\mathbf{1 7 )}}$. Although many therapeutic interventions are effective in experimental models of liver fibrosis, their efficacy and safety in humans are still unknown ${ }^{(4)}$

Pentoxifylline (PTX) is a trimethylated xanthine derivative which is widely used in disorders of vascular perfusion due to its favorable effects on erythrocyte deformability, erythrocyte oxygen delivery, and its properties as a peripheral vasodilator. PTX, also, improves liver perfusion in humans ${ }^{(\mathbf{1 8})}$.Pentoxifylline has been in use for more than 20 years (with minimal side effects) for the potent hemorrheologic properties and was recently discovered to have influence on function of some immune cells and production of cytokines especially TGF- $\beta 1^{(19) .}$

So, the aim of the present work is to evaluate the possible antifibrotic effect of pentoxifylline on experimentally induced schistosomal hepatic fibrosis and, also, to investigate its effect on serum leptin and TGF- $\beta 1$ levels as possible antifibrotic mechanisms in correlation with the hepatic fibrosis indices.

\section{MATERIALS \& METHODS}

\section{Parasite:}

Shistosoma mansoni cercariae shed from laboratory inbred infected Biomphalaria alexandrina snails, obtained from the Schistosome Biological Supply Program, Theodore
Bilharz Research Institute, Imbaba, Giza.

Animals:

In the study, ninety Swiss albino mice of both sexes were included. Mice were laboratory bred, parasite free, four weeks old and with average weight of 20-25 g. Mice were maintained with free access to commercial diet and water. Ten mice served as control non-infected, nontreated group and sacrificed for comparison. The remaining 80 mice were infected subcutaneously with 50 Schistosoma mansoni cercariae/mouse according to Peters and Warren ${ }^{(20)}$.

\section{Drug regimen:}

Praziquantel (PZQ) is available as Biltricide ${ }^{\circledR} 600 \mathrm{mg}$ tablets (Bayer Company), PZQ is an effective antischistosomal drug. It was given orally in a dose of $500 \mathrm{mg} / \mathrm{kg}$-body weight /dose according to Ismail et al. (21). That dose was followed by another dose after 9 days to assure killing of all eggs in the tissues, since PZQ has the capacity to kill only mature ova ${ }^{\text {(22). }}$

Pentoxifillyne (PTX) is available as Trental ${ }^{\circledR}$ tablets (Hoechest Company-Germany)). It was given orally in a dose of $50 \mathrm{mg} / \mathrm{kg} /$ day and continued for 4 weeks ${ }^{(23)}$.

Work protocol: The infected 80 mice were classified into the following groups:

Group I comprised 20 infected mice, not receiving any drug and served as an infected non-treated control group and divided into two subgroups: Subgroup Ia sacrificed at $9^{\text {th }}$ week post-infection and subgroup Ib sacrificed at $17^{\text {th }}$ week P.I. for comparison. 
Group II comprised 20 mice which received PZQ only. That group was divided into two subgroups: Subgroup IIa (10 mice) which received PZQ at the $6^{\text {th }}$ week P.I., subgroup IIb (10 mice) which received PZQ at the $14^{\text {th }}$ week P.I. These doses were followed by another dose after 9 days to assure killing of all eggs in the tissues (22).

Group III comprised 20 mice which received PTX only. That group was divided into two subgroups: subgroup IIIa (10 mice) which received PTX at the $6^{\text {th }}$ week P.I. daily and continued for four weeks (from $6^{\text {th }}$ to $9^{\text {th }}$ week P.I.) and subgroup IIIb (10 mice) which received PTX at the $14^{\text {th }}$ week P.I. for four weeks (from $14^{\text {th }}$ to $17^{\text {th }}$ week P.I).

Group IV comprised 20 mice which received a combination of both PZQ and PTX. That group was subdivided into two subgroups: Subgroup IVa (10 mice) which received PZQ and PTX at the $6^{\text {th }}$ week P.I .(PTX continued for 4 weeks) and subgroup IVb (10 mice) received PZQ and PTX at the $14^{\text {th }}$ week P.I. ( PTX continued for 4 weeks).

To assess the efficacy of PZQ and/or PTX on schistosomal hepatic fibrosis, animals of groups Ia, IIa, IIIa and IVa were sacrificed at the end of the $9^{\text {th }}$ week P.I. and animals of groups Ib, Iib, IIIb and IVb at the end of the $17^{\text {th }}$ week P.I.

Animals were killed by decapitation, blood samples were taken from every investigated animal, then transferred slowly into a dry sterile centrifuge tube, allowed to clot at room temperature for 30 minute, then centrifuged for 10 minutes at $5000 \mathrm{rpm}$. The clear supernatant serum was separated from the clot within two hours after collection and was stored in aliquots at $-20{ }^{\circ} \mathrm{C}$ for measurement of serum leptin and TGF- $\beta 1$ levels. Also, liver of all animals were removed and prepared for histopathological examination and measurement of granuloma size and assessment of liver hydroxyproline content.

Histopathological assay and measurement of granuloma size: One portion of the liver was fixed in $10 \%$ formalin and routinely dehydrated, embedded in paraffin and cut into sections $5 \mathrm{u}$ in thickness. Some sections were stained with haematoxylin and Eosin (H\&E) for histopathological examination and others stained with Masson's trichrome stain for collagen fibers staining. Measurement of the size of granulomas was done in H\&E stained sections by the use of computer assisted morphometric analyzer (MacScope, Mitani Corporation, Fukui, Japan). The mean diameter of each granuloma was obtained by measuring two perpendicular diameters, for each section, ten granulomas were measured and the mean diameter of all lesions was then calculated using the method described by Jacobs et al ${ }^{\text {(24) }}$.

Hydroxyproline assay: The other portion of the liver was frozen at - $20{ }^{\circ} \mathrm{C}$ and later processed for measurement of tissue hydroxyproline as described by Rice et al. ${ }^{\text {(25). }}$ Briefly, the protein was hydrolysed in $2 \mathrm{ml}$ of $6 \mathrm{~N} \mathrm{HCl}$ for 18 hours at $110^{\circ} \mathrm{C}$, then the reaction mixture was neutralized with sodium hydroxide titration to $\mathrm{pH}$ 7, and centrifuged at $1500 \mathrm{rpm}$. Hydroxyproline in the samples was reacted with oxidant $(1 \mathrm{ml}$ of 0.6 
$\mathrm{mol} / \mathrm{L}$ chloramine- $\mathrm{T}$ in acetate-citric acid buffer; Sigma) for 30 minutes and Ehrlich's reagent $(7.5 \%$ pdimethylaminobenzaldehyde; Sigma) in 60\% perchloric acid (Fisher Chemical, Fair Lawn, NJ) at $65^{\circ} \mathrm{C}$ for $15 \mathrm{~min}$, and hydroxyproline content was determined spectrophotometrically at $560 \mathrm{~nm}$. Liver hydroxyproline was quantitated against a standard curve set up with purified hydroxyproline (Sigma).

Assessment of serum TGF- $\beta 1$ : TGF $\beta 1$ was assayed by the Biosource Multispecies TGF- $\beta 1$ kit (BioSource Immunoassay kit, Catalog \# KAC 1688/KAC 1689). It is a solid phase sandwich Enzyme Linked Immunosorbent Assay (ELISA) ${ }^{(23)}$. TGF $\beta 1$ was assayed according to manufacturer's instructions.

Assessment of serum leptin: Leptin was estimated for measuring fibrogenesis ${ }^{(\mathbf{2 6 )}}$. Leptin was assayed by using Mouse Leptin ELISA Kit, (BioVendor, Cat. No: RD291001200). This kit is a sandwich ELISA method, used for the non- radioactive quantification of leptin in mice sera according to manufacturer's instructions.

\section{Statistical analysis:}

Analysis of the obtained data was conducted through the Mean, Standard deviation, independent sample Student's t-test, analysis of variance (ANOVA) followed by Tukey's test, rank and spearman correlation coefficient (r) tests using SPSS V.12

\section{RESULTS}

Eleven mice died during the course of the experiment; four mice from group I, two mice from group II, three mice from group III and two mice from group IV.

\section{Effects of drugs on hepatic granulomas size:}

The efficacy of treatment on granuloma diameters is shown in table (1). In comparison to the healthy liver of the control non-infected non-treated group (Fig. 1), H \& E stained sections of the livers of the infected nontreated mice killed at the $9^{\text {th }}$ week P.I. (group Ia) showed numerous viable eggs surrounded by large periovular cellular granulomas composed mainly of polymorphonuclear leucocytes, eosinophils, lymphocytes, plasma cells, small number of macrophages and fibroblasts with Schistosome pigment in portal areas (The mean diameter of granulomas was $600.50 \pm$ $69.28 \mu \mathrm{m}$ ) (Fig. 2). In infected nontreated mice, killed at the $17^{\text {th }}$ week P.I., (group Ib) the granulomas decreased in size (the mean diameter of granuloma was $515.05 \pm 92.47 \mu \mathrm{m}$ ) and become less cellular in comparison to mice killed at $9^{\text {th }}$ week P.I with marked increase in the connective tissue around the eggs, diminished eosinophils with relative increase in lymphocytes and development of periportal fibrosis (Fig. 3). The difference in granuloma size between group Ia and Ib was non significant.

In Masson's trichrome stained sections of group Ib, the collagen fibers appeared as abundant fibers oriented in various directions in some granulomas, while in others showed progressive accumulation and concentric orientation (Fig. 4). In the treated groups, significant reductions in granuloma size were detected in 
group IIa (infected and treated with PZQ only; $497.93 \pm 51.45 \mu \mathrm{m}$, $\mathrm{p}<0.05$ ) (Fig. 5), group IIIa (infected and treated with PTX alone; $429.44 \pm$ $47.45 \mu \mathrm{m}, \mathrm{p}<0.01$ ) (Fig. 6) and group IVa (infected and treated with both PZQ \& PTX; $188.66+36.82 \mu \mathrm{m}$, $\mathrm{p}<0.001$ ) at the $9^{\text {th }}$ week P.I. as compared to group Ia (infected and non treated, $600.50 \pm 69.28 \mu \mathrm{m})$. Also, significant reductions in granuloma size were detected at $17^{\text {th }}$ week P.I. in group IIb $(375.33 \pm 54.11$ $\mu \mathrm{m}, \mathrm{p}<0.05$ ) (Fig. 7), group IIIb $(266.42 \pm 39.06 \mu \mathrm{m}, \mathrm{p}<0.01)$ (Fig. 8) and group IVb $(141.97 \pm 39.72 \mu \mathrm{m}$, $\mathrm{p}<0.001$ ) (Fig. $9 \& 10$ ) as compared to group Ib $(515.05 \pm 92.47 \mu \mathrm{m})$. It was noticed that the eggs in groups II $(\mathrm{a} \& \mathrm{~b})$ and IV (a\&b) were dead, while eggs in groups I $(\mathrm{a} \& \mathrm{~b})$, III $(\mathrm{a} \& \mathrm{~b})$ were viable. However, the reduction in granuloma size is more significant in group III (PTX treated) than group II (PZQ treated) as compared to group I. The most significant reduction in granuloma size was detected in group IV as compared to groups I \& II \& III.

In Masson's trichrome stained sections, the collagen fibers fragmented and dispersed into a loose amorphous matrix in group II and III at the $17^{\text {th }}$ week P.I. (Fig. 11) while, in group IV, there was a marked resolution of collagen fibers and the granulomas were presented as small scars. (Fig. 12)

\section{Effects of drugs on hepatic hydroxyproline levels (HPO):}

The results of hepatic hydroxyproline (HPO) assay were presented in table (2). It was found that control infected non-treated group Ib showed a significant increase in total hepatic hydroxyproline levels at the $17^{\text {th }}$ week P.I. $(0.67 \pm 0.06 \mu \mathrm{g} / \mathrm{g})$ as compared to group $\mathrm{Ia}$ at the $9^{\text {th }}$ week P.I. $(0.46 \pm 0.08 \mu \mathrm{g} / \mathrm{g}, \mathrm{p}<0.001)$. As regards treated groups, it was found that there were significant decreases in hepatic HPO in groups IIa $(0.27+0.05 \mu / g, p<0.05)$, IIIa $(0.26 \pm 0.06 \mu \mathrm{g} / \mathrm{g}, \mathrm{p}<0.01)$, and IVa $(0.18 \pm 0.04 \mu \mathrm{g} / \mathrm{g}, \quad \mathrm{p}<0.001)$ as compared to group Ia $(0.46 \pm 0.08$ $\mu \mathrm{g} / \mathrm{g})$ at $9^{\text {th }}$ week P.I. Also, there were significant decreases in hepatic HPO in groups IIb $(0.42 \pm 0.07 \mu \mathrm{g} / \mathrm{g}$, $\mathrm{p}<0.05)$, IIIb $(0.36 \pm 0.05 \mu \mathrm{g} / \mathrm{g}$, $\mathrm{p}<0.01)$, and IVb $(0.27 \pm 0.15 \mu \mathrm{g} / \mathrm{g}$, $\mathrm{p}<0.001)$ as compared to group Ib $(0.67 \pm 0.06 \mu \mathrm{g} / \mathrm{g})$ at $17^{\text {th }}$ week P.I. The reduction in HPO is more significant in group III (PTX treated) than group II (PZQ) as compared to group I. Moreover, the most significant decrease in liver HPO was observed in group IVa\&b which received a combination of PTX \& PZQ as compared to groups Ia\&b, IIa\&b and IIIa\&b. The decrease in hepatic HPO content, when treatment started early (from $6^{\text {th }}$ to $9^{\text {th }}$ week P.I.) was more significant than when treatment started late (from $14^{\text {th }}$ to $17^{\text {th }}$ week P.I.) in all treated groups.

Effects of drugs on serum TGF- 11 levels

The results of serum TGF- $\beta 1$ levels was presented in table (3). It was observed that serum TGF- $\beta 1$ level was markedly increased in the infected, non-treated group: Ia (197.28 $\pm 11.41 \mathrm{pg} / \mathrm{ml}) \& \mathrm{Ib}(330.03 \pm 35.15$ $\mathrm{pg} / \mathrm{ml})$ ) as compared with the control non infected, non-treated group $(121.99 \pm 5.74 \mathrm{pg} / \mathrm{ml}))$ with a significant difference $(\mathrm{p}<0.01$ and $\mathrm{p}<0.001$ respectively). As regards treated groups, serum TGF- $\beta 1$ levels 
were decreased in groups IIa

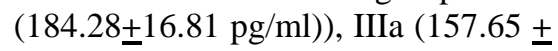
$13.62 \mathrm{pg} / \mathrm{ml})) \&$ and IVa (138.02 \pm $11.22 \mathrm{pg} / \mathrm{ml})$ ) in comparison to the infected non-treated group (group Ia) at the $9^{\text {th }}$ week P.I. with significant differences only in group IIIa $(\mathrm{p}<0.001)$ and IVa $(\mathrm{p}<0.001)$. Also, serum TGF- $\beta 1$ levels were decreased in groups IIb $(282.40 \pm 32.94 \mathrm{pg} / \mathrm{ml}))$, IIIb $(199.72 \pm 11.20 \overline{\mathrm{pg}} / \mathrm{ml})) \&$ and IVb $(164.85 \pm 22.98 \mathrm{pg} / \mathrm{ml}))$ in comparison to the group $\mathrm{Ib}$; the infected non-treated group (330.03 \pm $35.15 \mathrm{pg} / \mathrm{ml})$ ) at the $17^{\text {th }}$ week P.I. with significant differences only in group IIIb $(\mathrm{p}<0.001)$ and IVb $(p<0.001)$. The decrease of TGF- $\beta 1$ in PZQ treated group is non significant at the $9^{\text {th }}$ and $17^{\text {th }}$ weeks P.I as compared to group I (a\&b). The most significant decrease in serum TGF- $\beta 1$ level was detected in group IVa \& IVb (treated with PTX \& PZQ) as compared to other groups.

\section{Effects of drugs on serum leptin levels:}

The results of serum leptin were presented in Table (4). It was observed that serum leptin level was markedly increased in group Ia (17.30 $\pm 2.55 \mathrm{ng} / \mathrm{ml}) \& \mathrm{Ib}(26.02 \pm 2.41$ $\overline{\mathrm{ng}} / \mathrm{ml}$ ) (infected and non-treated) as compared with the non infected non- treated control group $(1.87 \pm 0.41$ $\mathrm{ng} / \mathrm{ml}$ ) with a significant difference $(p<0.001)$ at $9^{\text {th }}$ and $17^{\text {th }}$ weeks P.I.. As regards treated groups, serum leptin levels were decreased in groups IIa $(14.66 \pm 2.20 \mathrm{ng} / \mathrm{ml})$ IIIa $(10.84 \pm$ $1.94 \mathrm{ng} / \mathrm{ml})$ and IVa $(4.50 \pm 0.90$ $\mathrm{ng} / \mathrm{ml}$ ) in comparison to the infected non-treated group (group Ia) but with only significant differences at groups IIIa $(p<0.001)$ and IVa $(p<0.001)$. Also, serum leptin levels were decreased in groups IIb $(23.85 \pm 3.06$ $\mathrm{ng} / \mathrm{ml}))$, IIIb $(14.91 \pm 2.20 \mathrm{ng} / \mathrm{ml})$ and $\operatorname{IVb}(5.31 \pm 1.7 \mathrm{ng} / \mathrm{ml}))$ in comparison to the infected non-treated group (group Ib) but with significant differences only at groups IIIb and IVb $(p<0.001)$. The decrease of serum leptin level in PZQ treated group was non signficant as compared to group I at the $9^{\text {th }}$ and $17^{\text {th }}$ weeks P.I. The most significant decrease in serum leptin level was detected in group IVa and group IVb (treated with PTX \& PZQ) as compared to other groups.

Table (5) and Fig (13, 14 \& 15) showed significant correlation between granuloma size in liver of mice and hepatic HPO (collagen content) $(\mathrm{p}<0.001)$, granuloma size and serum TGF-B1 levels $(\mathrm{p}<0.05)$ and granuloma size and serum leptin levels $(\mathrm{p}<0.05)$. 
Table (1): The mean diameters of ganulomas $(\mu \mathrm{m})$ in the studied groups at $9^{\text {th }} \&$ $17^{\text {th }}$ weeks P.I.

\begin{tabular}{|c|c|c|c|}
\hline \multirow{2}{*}{$\begin{array}{l}\text { Sudied } \\
\text { group }\end{array}$} & $9^{\text {th }}$ week P.I. (Ia) & $17^{\text {th }}$ week P.I. (Ib) & \multirow{2}{*}{ ANOVA tukey's test } \\
\hline & Mean \pm SD & Mean \pm SD & \\
\hline group I & $600.50 \pm 69.28^{\mathrm{a}^{* * *}}$ & $515.05+92.47^{\mathrm{a}^{* * *}}$ & $\begin{array}{l}\text { GIa> GIIa- GIa>GIIIa- } \\
\text { GIa>GIVa- GIb }>\text { GIIb- GIb> } \\
\text { GIIIb- GIb> GIV }\end{array}$ \\
\hline group II & $497.93 \pm 51.45^{\neq^{*} \mathrm{a}^{* * * *}}$ & $375.33 \pm 54.11^{\neq * \mathbf{a}^{* * * *}}$ & $\begin{array}{l}\text { GIIa }<\text { GIa-GIIb }<\text { GIb- GIIa }> \\
\text { GIVa- GIIb }>\text { GIVb }\end{array}$ \\
\hline group III & $429.44+47.45^{\#^{* *} \mathrm{a}^{* * *}}$ & $266.42+39.06^{\neq * *} \mathbf{a}^{*}$ & GIIIa $<$ GIa-GIIIb $<$ GIb \\
\hline group IV & $188.66+36.82^{\neq^{* * * *}}$ & $141.97 \pm 39.72^{\neq * * * *}$ & $\begin{array}{l}\text { GIVa }<\text { GIa- GIVa }<\text { GIIa., GIVa }< \\
\text { GIIIa- GIVb }<\text { GIb-GIVb }<\text { GIIb- } \\
\text { GIVb }<\text { GIIb }\end{array}$ \\
\hline
\end{tabular}

Tukey's test $P<0.05$ significant.

* Significant at $<0.05 \quad * * \quad$ Significant at $<0.01 \quad * * *$ Significant at $<0.001$.

$\neq$ : Significant with group I.

a : Significant with group IV.

Group IV was the most significant as compared to all other groups.

Table (2): Estimated hydroxyproline levels ( $\mu \mathrm{g} / \mathrm{g}$ liver tissue) among the studied groups at $9^{\text {th }} \& 17^{\text {th }}$ weeks P.I.

\begin{tabular}{|c|c|c|c|}
\hline \multirow{2}{*}{$\begin{array}{l}\text { Studied } \\
\text { group }\end{array}$} & $9^{\text {th }}$ week P.I. & $17^{\text {th }}$ week P.I. & \multirow{2}{*}{ ANOVA tukey's test } \\
\hline & Mean \pm SD & Mean \pm SD & \\
\hline group I & $0.46 \pm 0.08^{\mathrm{a}^{* * *}}$ & $0.67 \pm 0.06^{\mathrm{a}^{* * *}}$ & $\begin{array}{l}\text { GIa }<\text { Ib- GIa }>\text { IIIa- GIa }>\text { IVa-GIb }>\text { GIIb- } \\
\text { GIb }>\text { IIIb- GIb }>\text { GIVb }\end{array}$ \\
\hline group II & $0.27 \pm 0.05^{\neq^{*} \mathrm{a}^{*}}$ & $0.42+0.07^{\#^{*} \mathrm{a}^{* *}}$ & $\begin{array}{l}\text { GIIa }<\text { GIa- GIIa }>\text { GIVa- GIIb }<\text { GIb- } \\
\text { GIIb }>\text { GIVb }\end{array}$ \\
\hline group III & $0.26 \pm 0.06^{\neq^{* * *} \mathbf{a}^{*}}$ & $0.36 \pm 0.05^{\neq^{* *} \mathbf{a}^{*}}$ & $\begin{array}{l}\text { GIIIa }<\text { GIa- GIIIa }>\text { IVa- GIIIb }<\text { GIb- } \\
\text { GIIIb }>\text { GIVb }\end{array}$ \\
\hline group IV & $0.18 \pm 0.04^{\neq^{* * * *}}$ & $0.27 \pm 0.15^{\#^{* * * *}}$ & $\begin{array}{l}\text { GIVa }<\text { GIa- GIVa }<\text { GIIa., GIVa }< \\
\text { GIIIa- GIVb }<\text { GIb-GIVb }<\text { GIIb- } \\
\text { GIVb }<\text { GIIb }\end{array}$ \\
\hline
\end{tabular}

Tukey's test $P<0.05$ significant.

* Significant at $<0.05 * *$ Significant at $<0.01 * * *$ Significant $<0.001$.

$\neq$ : Significant with group I.

$a$ : Significant with group IV.

Group IV was the most significant as compared to all other groups. 
Table (3): Serum TGF- $\beta 1$ levels (pg/ml) among the studied groups at $9^{\text {th }} \& 17^{\text {th }}$ weeks P.I.

\begin{tabular}{|c|c|c|c|}
\hline \multirow{2}{*}{$\begin{array}{l}\text { Sudied } \\
\text { group }\end{array}$} & $9^{\text {th }}$ week P.I. & $17^{\text {th }}$ week P.I. & \multirow{2}{*}{ ANOVA tukey's test } \\
\hline & Mean \pm SD & Mean \pm SD & \\
\hline group I & $197.28 \pm 11.41^{\mathrm{a}^{* * *}}$ & $330.03+35.15^{\mathrm{a}^{* * *}}$ & $\begin{array}{l}\text { GIa> control- GIa }>\text { GIIIa- GIa }> \\
\text { GIVa- GIb }>\text { control- - GIb }> \\
\text { GIIIb- GIb }>\text { GIVb }\end{array}$ \\
\hline group II & $184.28 \pm 16.81^{\mathrm{a}^{* * * *}}$ & $282.40 \pm 32.94^{\mathrm{a}^{* * * *}}$ & $\begin{array}{l}\text { GIIa }>\text { GIVa- GIIa }>\text { GIIIa - GIIa> } \\
\text { GIIIb-GIIb }>\text { GIVb }\end{array}$ \\
\hline group III & $157.65 \pm 13.62^{\neq * * *} \mathbf{a}^{* * * *}$ & $199.72 \pm 11.20^{\neq * * *} \mathrm{a}^{* * *}$ & $\begin{array}{l}\text { GIIIa }<\text { GIa- GIIIa }>\text { GIVa- } \\
\text { GIIIb }<\text { GIb- GIIIb }>\text { GIVb }\end{array}$ \\
\hline group IV & $138.02 \pm 11.22^{\#^{* * * *}}$ & $164.85+22.98^{f^{* * * *}}$ & $\begin{array}{l}\text { GIVa }<\text { GIa- GIVa }<\text { GIIa., } \\
\text { GIVa }<\text { GIIIa- GIVb }>\text { GIb- } \\
\text { GIVb }<\text { GIIIb- }\end{array}$ \\
\hline $\begin{array}{l}\text { Control non } \\
\text { infected gr. }\end{array}$ & & $121.99 \pm$ & \\
\hline
\end{tabular}

Tukey's test $P<0.05$ significant.

$*$ Significant at $<0.05 * *$ Significant at $<0.01 \quad * * *$ Significant at $<0.001$.

$\neq$ : Significant with group I.

$a$ : Significant with group IV.

Group IV was the most significant as compared to all other groups.

Table (4): Serum leptin levels (ng/ml) among the studied groups at $9^{\text {th }} \& 17^{\text {th }}$ weeks P.I.

\begin{tabular}{|c|c|c|c|}
\hline \multirow{2}{*}{ Studied group } & $9^{\text {th }}$ week P.I. & $17^{\text {th }}$ week P.I. & \multirow{2}{*}{ ANOVA tukey's test } \\
\hline & Mean \pm SD & Mean \pm SD & \\
\hline group I & $17.30 \pm 2.55^{\mathrm{a}^{* * *}}$ & $26.02+2.41^{\mathrm{a}^{* * *}}$ & $\begin{array}{l}\text { GIa }>\text { control- GIa }>\text { GIIIa- GIa }>\text { GIVa- } \\
\text { GIb }>\text { control- } \quad \text { GIb }>\text { GIIIb- } \\
\text { GIb }>\text { GIVb }\end{array}$ \\
\hline group II & $14.66+2.20^{\mathrm{a}^{* * *}}$ & $23.85+3.06^{\mathrm{a}^{* * * *}}$ & GIIa $>$ GIVa- GIIb $>$ GIVb \\
\hline group III & $10.84 \pm 1.94^{\#^{* * *} \mathbf{a}^{*}}$ & $14.91 \pm 2.20^{\#^{* * * *} \mathbf{a}^{* * *}}$ & $\begin{array}{l}\text { GIIIa }<\text { GIa- GIIIa }>\text { GIVa- GIIIb }<\text { GIb- } \\
\text { GIIIb }>\text { GIVb }\end{array}$ \\
\hline group IV & $4.50 \pm 0.90^{\neq * * *}$ & $5.31 \pm 1.7^{\neq * * *}$ & $\begin{array}{l}\text { GIVa }<\text { GIa- GIVa }<\text { GIIa., GIVa }< \\
\text { GIIIa- GIVb }>\text { GIb-GIVb }<\text { GIIIb- }\end{array}$ \\
\hline $\begin{array}{l}\text { Control non } \\
\text { infected group }\end{array}$ & \multicolumn{3}{|l|}{$1.87+0.41$} \\
\hline
\end{tabular}

Tukey's test $P<0.05$ significant.

* Significant at $<0.05 * *$ Significant at $<0.01 \quad * * *$ Significant at $<0.001$.

$\neq$ : Significant with group I.

$a$ : Significant with group IV.

Group IV was the most significant as compared to all other groups. 
Table (5): Simple linear correlation (r) between granuloma size and other parameters of the study

\begin{tabular}{|l|l|l|}
\hline & r & P. value \\
\hline granuloma size \& hydroxyprloline & $0.654^{* * *}$ & $<0.001$ \\
\hline granuloma size \& TGF-B1 level & $0.411^{*}$ & $<0.05$ \\
\hline granuloma size \& leptin levels & $0.397^{*}$ & $<0.05$ \\
\hline
\end{tabular}

Significant at $P<(0.05)$

*** Significant at $P<(0.001)$

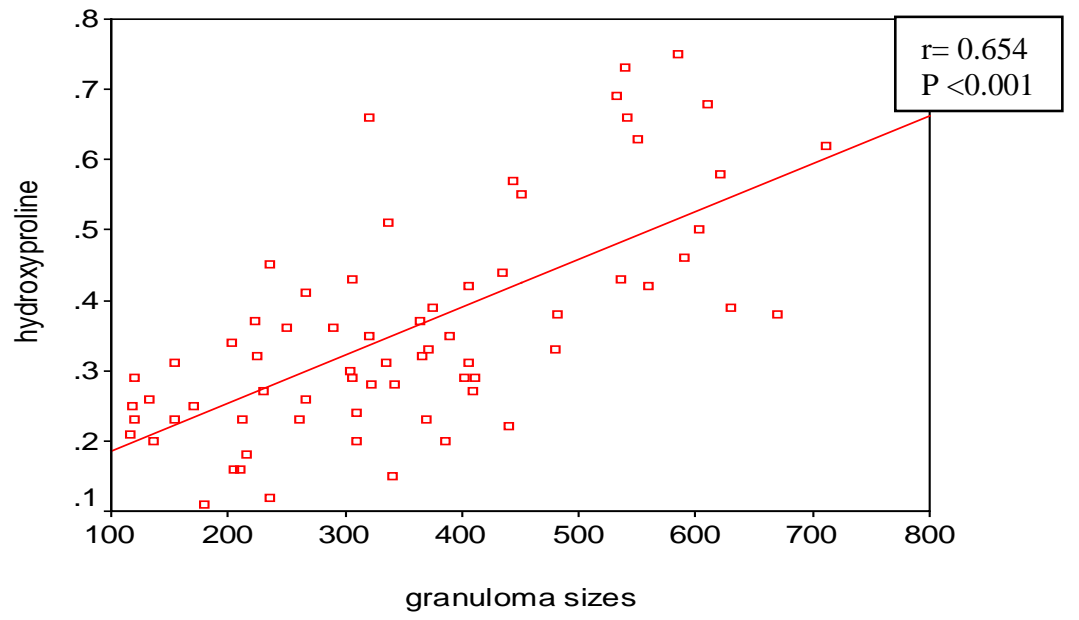

Fig (13): Correlation between granuloma size and hepatic hydroxyproline levels

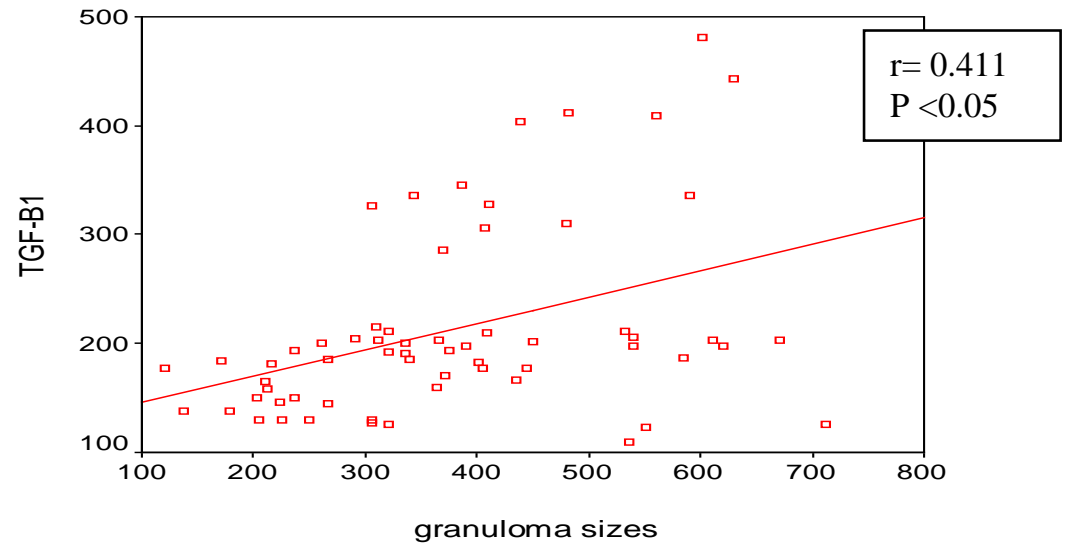

Fig (14): Correlation between granuloma size and serum levels of TGF--ß1 


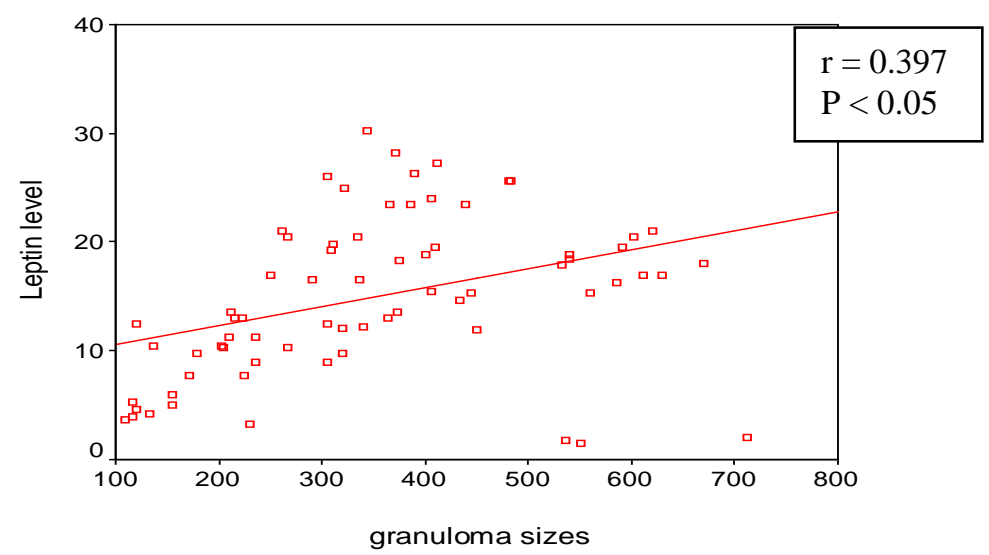

Fig (15): Correlation between granuloma size and serum levels of leptin

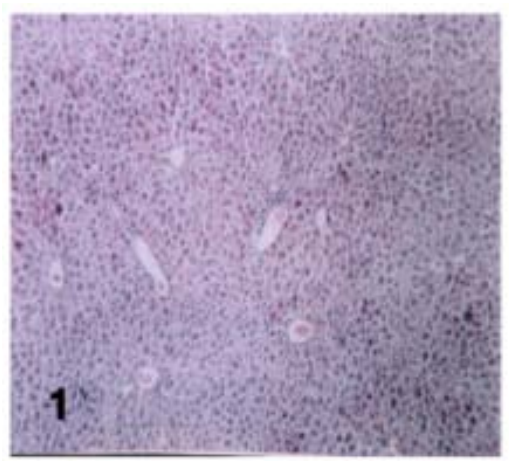

Fig. (1): A liver section of a control non-infected non-treated mouse showing normal liver arcitecture (H \& E, X 200).

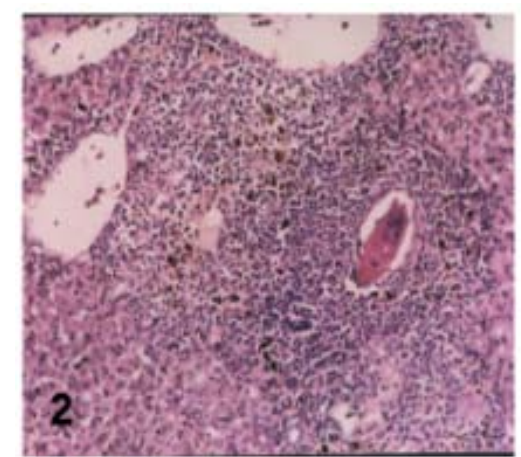

Fig. (2): A liver section of control infected non-treated mouse at $9^{\text {th }}$ week P.I. (group Ia) showing cellular bilharzial granulomas with collections of eosinophils, mononuclear cells and macrophages around viable eggs (H\&E, X 400). 


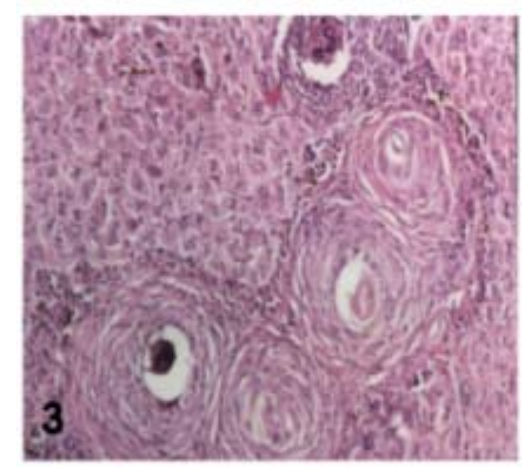

Fig. (3): A liver section of control infected non-treated mouse at $17^{\text {th }}$ week P.I. (group Ib) showing bilharzial granulomas with increased connective tissues around eggs and reduced cellularity giving whorly appearance (H\&E, X 250).

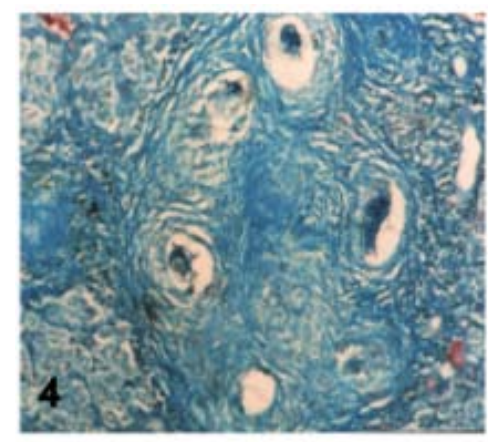

Fig. (4): A liver section of control infected non-treated mouse at $17^{\text {th }}$ week P.I. (group Ib) showing multiple bilharzial granulomas with concentric collagen fibers oriented in various directions (Masson's trichrome, X250).

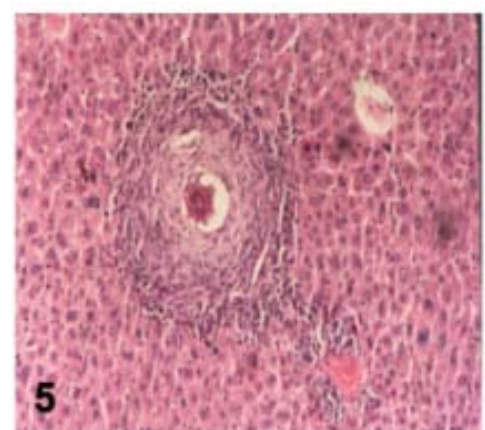

Fig. (5): A liver section of a mouse of group IIa (infected and treated with PZQ) at $9^{\text {th }}$ week P.I showing decrease in granuloma size with dead egg in the centre (H\&E, X400). 


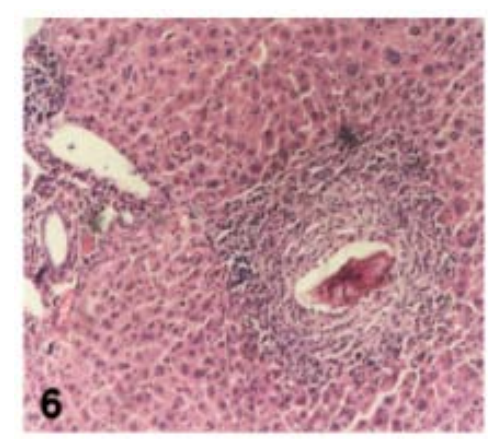

Fig. (6): A liver section of a mouse of group IIIa (infected and treated with PTX) at $9^{\text {th }}$ week P.I showing decrease in granuloma size with healthy egg in the centre (H\&E, X400).

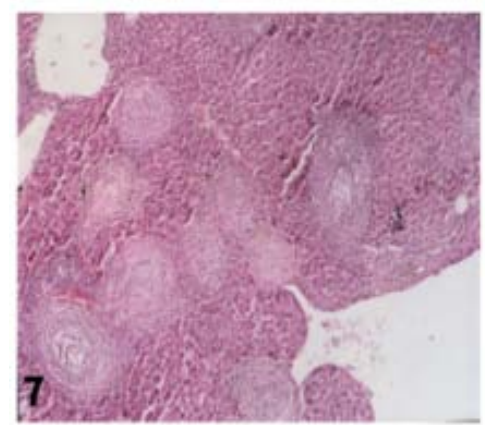

Fig. (7): A liver section of a mouse of group IIb (infected and treated with PZQ) at $17^{\text {th }}$ week P.I showing mild decrease in granuloma size (H\&E, X250).

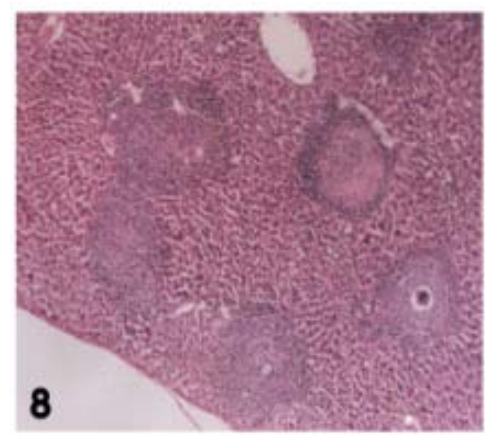

Fig. (8): A liver section of a mouse of group IIIb (infected antd treated with PTX) at $17^{\text {th }}$ week P.I showing moderate decrease in granuloma size (H\&E, X250). 

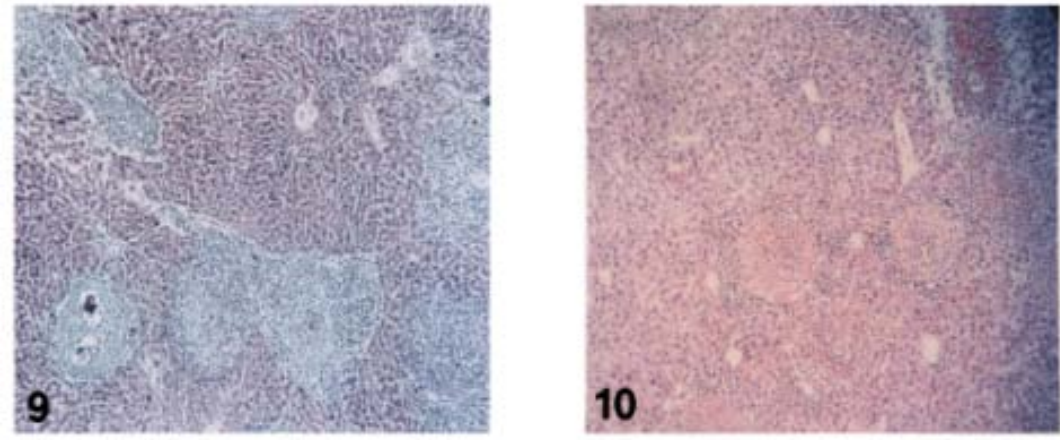

Fig. (9,10): A liver section of a mouse of group VIb (infected and treated with PZQ \& PTX) at $17^{\text {th }}$ week P.I showing marked decrease in granuloma size with increased cellularity (H\&E, X250).

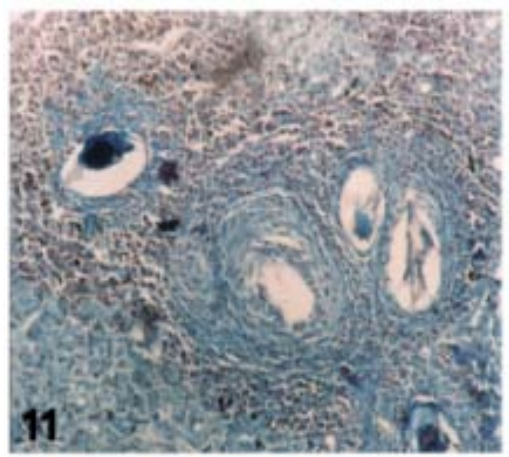

Fig (11): A liver section of a mouse of group IIIb (infected and treated with PTX) at $17^{\text {th }}$ week P.I showing collagen fibers fragmented and scanty (Masson's trichrome, X250).

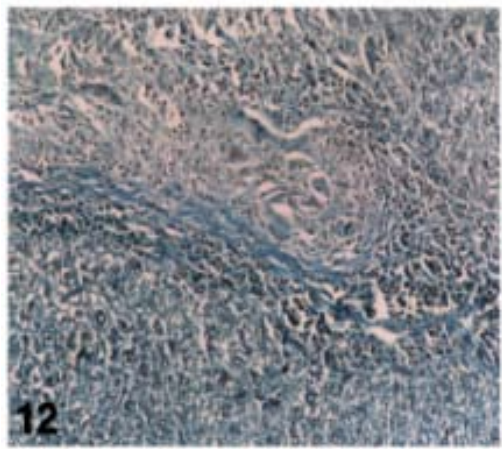

Fig (12): A liver section of a mouse of group VIb (infected and treated with PZQ \& PTX) at $17^{\text {th }}$ week P.I showing scarring (Masson's trichrome, X250). 


\section{DISCUSSION}

Schistosomal hepatic fibrosis is a complex process due to increased synthesis and deposition of extracellular matrix component where cytokines play a pivotal role. Liver fibrosis is the body's wound healing response to injury where a typical cascade of events occurs (27). That cascade includes injury; often with a component of oxidative stress which itself can amplify the fibrogenic cascade, followed by mobilization of the inflammatory cells. The latter release cytokines that amplify the overall response and contribute to the activation of the effector cells. Typical effector cells are matrix producing cells such as hepatic stellate cells (HSCs). More than the normal amount of collagen fiber deposits in the extracellular spaces of the liver cells and causes the liver cells to lose blood infusion and to be hardened during fibrosis ${ }^{(28)}$

It is important to emphasize that factors controlling activation of these cells are multifactorial and complex, and thus multiple potential therapeutic interventions are possible. A further critical concept is that the fibrogenic lesion, in particular, the extracellular matrix, is dynamic and reversible. Even advanced fibrosis may be reversible under the appropriate conditions ${ }^{(29)}$.

Understanding of the basis of hepatic fibrogenesis has advanced significantly in the past two decades, and with it, a field dedicated to therapeutic antifibrotics has emerged. A number of specific antifibrotic therapies have been tried, but have been met with poor or no success.
However, elucidation of the mechanisms responsible for fibrogenesis, with particular emphasis on stellate cell biology and the mechanisms underlying fibrogenesis has highlighted many putative novel therapies.(30)

Inhibition of cytokine-stimulated matrix production is a mainstay of antifibrotic treatment for a variety of indications. That approach involves blocking of matrix synthesis and processing or inhibition of the activity of TGF- $ß 1$, the major fibrogenic cytokine. TGF-ß1-antagonists are undergoing extensive testing because neutralization of that potent cytokine would have the dual effect of inhibiting matrix production and accelerating its degradation ${ }^{(30)}$. Targeting of antifibrotic drugs to HSCs and fibrogenic cytokines is a promising strategy to block the fibrotic process ${ }^{(31)}$.

In the current study, pentoxifylline was tested alone and in combination with praziquantel for treatment of schistosomal hepatic fibrosis. Histopathological examination of liver sections of group I (infected and non-treated) showed a non significant reduction in granuloma size with decreased cellularity in group Ib (infected nontreated, examined at $17^{\text {th }}$ week P.I.) as compared to group Ia (infected nontreated, examined at $9^{\text {th }}$ week P.I.). The decrease in granuloma size in group Ib could be explained by the natural immunomodulation of granuloma ${ }^{(32)}$.

The present study, also, showed significant reduction in both granuloma size and hepatic hydroxyproline levels in PZQ treated 
group (IIa \& IIb), when compared to the control one either in group Ia \& Ib. The decrease in both granuloma size and hepatic hydroxyproline levels in group II could be explained on the basis of the findings of Ebeid ${ }^{(33)}$ who stated that once a mouse is cured from Schistosoma, granulomatous lesions in the liver shrink progressively afterwards, disappearing in 4 to 6 weeks after treatment, leaving scars. This, also, agreed with Giboda and Smith ${ }^{\text {(34) }}$ who found that once curing schistosomal infection prevents new eggs from reaching the liver and those that are already present remain acitve and viable for a maximum of 15 days. On the other hand, PZQ caused a decrease in the levels of serum TGFB1 and leptin but the decreases were non significant as compared to group I.

Pentoxifylline resulted in significant improvement in the estimated parameters of hepatic fibrosis (decreased in granuloma size, liver HPO, serum TGF- $\beta 1$ and leptin levels) in group III as compared to group I. The reduction in granuloma size in PTX group was more significant than PZQ group when compared to group I. Preaux et al. ${ }^{(35)}$ stated that the decrease in granuloma size might be due to some toxic effect of PTZ on egg release or adult worm fecundity. They explained that the significant decrease in hepatic HPO by PTX was due to its reported antiproliferative effect on cytokine induced mitogenesis in fibroblasts and myofibroblasts, inhibition of extracellular matrix synthesis as well as reduction of HSCs proliferation which are cells involved in collagen synthesis in liver.
The results of the present study were in accordance with those of Reis et al. ${ }^{(36)}$ who studied the effects of PTX on murine schistosomal hepatic fibrosis. They demonstrated that PTX decreased granuloma size and numbers in murine hepatic Schistosoma. They explained that the anti-fibrotic action of PTX on hepatic stellate cells was in response to transforming growth factor beta 1 (TGF B1) mediated by extracellular collagen degradation rather than by a reduction of collagen synthesis. They added that the lack of PTX effect on collagen synthesis might be due to the fact that the drug was administered after granulomas elicitation, when immune component cells were already stimulated. Furthermore, the decrease in the number of involutive granulomas could be paradoxically explained by PTX collagenase stimulation, an aspect already demonstrated by Berman and Duncan $^{(37)}$ accelerating the time of granuloma disappearance.

Most

importantly, histopathological examination of liver and biochemical assays have revealed that group IV which received the combined therapy pf PZQ and PTX, showed the most significant reduction in fibrotic parameters (diminished ganulomas size, hepatic hydroxyproline levels, decreased serum TGF $\beta 1$ and serum leptin levels) in comparison to group I (infected and non-treated), group II (given PZQ only) and III (given PTX only). In Masson's trichrome stained sections for collagen staining, there was marked resolution of collagen in mice of group IV that treated with combined therapy (PZQ \& PTX), 
while there was scanty collagen in group II (treated with PZQ) and III (treated with PTX only).

Collagen is secreted as a propeptide that contains high proportion of proline; the hydroxyproline arise from hydroxylation of proline residues by proline hydroxylase. The collagen accumulation could be inhibited by blocking proline hydroxylase activity. A common sense dictates that the earlier a fibrotic lesion is detected, the more likely it is to be amenable to therapy ${ }^{(\mathbf{3 8})}$. The results of that study showed that a more significant decrease was observed in HPO content when treatment started early at the $6^{\text {th }}$ week P.I. than at $14^{\text {th }}$ week P.I. in the treated groups.

Xiong et al. ${ }^{(23)}$ explained the capability of PTX to reduce the hepatic schistosomal fibrosis in a mouse model by its ability to decrease TGF- B1, type I and type III collagens in hepatic tissue of mice with fibrosis. They stated that the ability of PTX to reduce the hepatic content of collagen III is similar to PZQ and its effects on TGF-B1 and type I collagen are weaker than PZQ.

Raetsch et al. $^{(17)}$ found that suppression of stellate cells and myofibroblasts by PTX appears to involve at least three different mechanisms that act in part downstream of an increase in intracellular cAMP: First, inhibition of procollagen I and III expression at a pretranslational level by downregulation of nuclear factor 1 , a positive transcriptional regulator of interstitial procollagen genes, which is upregulated by TGF-ß1; Second, enhanced intracellular degradation of procollagen prior to its secretion and extracellular deposition as fibrils; Third, inhibition of platelet derived growth factor induced mitogenicity by interference with the activation of the mitogen activated protein kinase, a central event in the signalling cascade downstream of the activated platelet derived growth factor receptor.

On the contrary, Tarcin et al. $^{(39)}$ concluded that PTX, interferon alpha and their combination have no beneficial effect on experimental fibrosis induced by biliary obstruction.

Concerning serum leptin and TGF-ß1 levels, in the present study, they showed marked increase in the infected non-treated group as compared to non-infected, non treated group indicating that leptin is a profibrogenic cytokine. Significant decrease in serum leptin levels were observed in group III (PTX treated) and group IV (PZQ and PTX treated) while the decrease in serum leptin levels in group II (PZQ treated) were non significant. The most significant decreases in serum leptin and TGF-ß1 were observed in group IV which treated with a combination of PZQ and PTX. Several reports have implicated leptin as critical hormone in the development of liver fibrogenesis. In a number of studies, administration of recombinant leptin augmented hepatic fibrogenesis induced by hepatotoxic chemicals ${ }^{(\mathbf{4 0})}$. Further, leptin-deficient ob/ob mice and leptin receptor (ObR)-deficient Zucker rats exhibit extremely poor profibrogenic responses in the liver caused by carbon tetrachloride $\left(\mathrm{CCl}_{4}\right)^{(41)}$, thioacetamide (TAA) ${ }^{(42)}$ and Schistosoma infection ${ }^{(10 \& 12)}$. 
Ikejima et al. ${ }^{(\mathbf{4 3})}$ stated that in these animal studies, leptin was shown to have only a permissive role in liver fibrosis, acting primarily by enhancing transforming growth factor ß1 mRNA in isolated sinusoidal endothelial cells and Kupffer cells, suggesting that leptin promotes hepatic fibrogenesis through upregulation of TGF $ß 1$ in the liver.

Novel mechanisms were provided to explain how leptin affect liver fibrogenesis. Genes associated with liver fibrosis (for example: tissue inhibitors of metalloproteinases) are being studied to determine whether leptin alters their expression and in turn acts as a profibrogenic substance in the liver microenvironment. Emerging evidence suggested that leptin could act through certain signaling cascade, including the family of mitogen-activated-protein kinase and the stress-activated protein kinase. Mitogen activated-protein kinase and the stress-activated protein kinase could explain the persistent increase in collagen gene activation and expression by leptin in HSCs ${ }^{(\mathbf{4 4}) \text {. }}$

Moreover, Cao et al. ${ }^{(45)}$ in their study, concluded that leptin enhances alpha I collagen gene expression in HSCs stimulating collagen production through $\mathrm{H}_{2} \mathrm{O}_{2}$-dependent mechanism. Accordingly, they postulated that interference with leptin-induced oxidative stress by antioxidant might provide an opportunity for prevention of liver fibrosis. By real-time reverse transcriptase-polymerase chain reaction, Ding et al. ${ }^{(\mathbf{4 6})}$ confirmed the presence of leptin in activated but not quiescent HSCs, whereas only quiescent HSCs synthesized adiponectin mRNA and protein. adiponectin receptors were detected in both activated and quiescent HSCs, but only activated HSCs produced significant apoptosis after treatment with adiponectin.

Treatment with antifibrotic drugs not only prevent cross-linking of newly synthesized collagen during formation of the granulomas but, affects, also, granuloma morphology and the functional status of the granuloma cells that become less responsive to soluble egg antigen ${ }^{(\mathbf{4 4})}$. Recent researches should investigate the molecular mechanisms that cause fibrosis in different types of human liver diseases in order to identify new targets for therapy. Developing simple and reliable non-invasive markers of hepatic fibrosis is an important goal in clinical hepatology and will facilitate the design of clinical trial. Most importantly, the efficacy of antifibrotic drugs known to attenuate experimental liver fibrosis should be tested in human.

In conclusion, Pentoxifylline (PTX) is a promising antifibrotic drug, acting by reducing serum TGF- $\$ 1$ and leptin levels in the experimental schistosomal hepatic fibrosis. Also, the use of this antifibrotic drug in combination with the antischistosomal drug, praziquantel (PZQ), is very effective in the control of fibrotic processes in schistosomal hepatic fibrosis.

\section{REFERENCES}

1. Giboda, $M$ and Smith J.M. (1997): Impact of antifibrotic treatment on the course of Schistosoma mansoni infection in 
murine model. Med. Inst. Oswaldo Cruz., : 693-697.

2. Benyon, R.C. and Iredale, J.P. (2000): Is liver fibrosis reversible. Gut 46:443-446.

3. Arthur, M.J. (2000): Fibrogenesis II. Metalloproteinases and their inhibitors in liver fibrosis. Am. J. Physiol. Gastrointest. Liver Physiol. 279:G245-G249.

4. Gabele, E., Brenner, D.A., and Rippe, R.A. (2003):. Liver fibrosis: signals leading to the amplification of the fibrogenic hepatic stellate cell. Front. Biosci., 8:D69-D77.

5. Bataller, R. and Brenner, D.A. (2001): Hepatic stellate cells as a target for the treatment of liver fibrosis. Semin. Liver Dis., 21:437-451.

6. Marra, F. (1999): Hepatic stellate cells and the regulation of liver inflammation. J. Hepatol., 31:1120-1130.

7. Giboda M, Jacobs $\mathbf{P}$ and Smith JM (1995): Immune response of mice infected with Schistosoma mansoni is modulated by antifibrotic treatment. Ann. Trop. Med. Parasitol., 89(4): 415-424.

8. Lindquist, J.N., Marzluff, W.F., and Stefanovic, B. (2000): Fibrogenesis. III. posttranscriptional regulation of type I collagen. Am. J. Physiol. Gastrointest. Liver Physiol., 279:G471-G476.

9. Marra, F. (2002): Leptin and liver fibrosis: a matter of fat. Gastroenterology 122:1529-1532.

10. Saxena NK, Ikeda K, Rockey DC, Friedman SL and Anania FA (2002): Leptin in hepatic fibrosis: evidence for increased collagen production in stellate cells and lean littermates of ob/ob mice. Hepatology 35 : 762-771.

11. Ikejima, K. (2002): Leptin receptor-mediated signaling regulates epatic fibrogenesis and remodeling of extracellular matrix in the rat Gastroenterolog. 122:1399-1410.

12. Kamada, Y. (2003): Enhanced carbon tetrachloride-induced liver fibrosis in mice lacking adiponectin. Gastroenterology 125:1796-1807.

13. Cioli D (2000): Praziquantel: is there a real resistance and are there alternatives ? Curr. Opin. Infect. Dis., 13 : 659-663

14. Bataller, R., North, K.E., and Brenner, D.A. (2003.): Genetic polymorphisms and the progression of liver fibrosis: a critical appraisal. Hepatology. 37:493-503.

15. Bissell DM (2001): Chronic liver injury, TGF-beta, and cancer. Exp. Mol. Med., 33: 190 -197.

16. Fuchs EC, Gressene AM, and Weyhenmayer $R$ (1995): Identification of the antifibrogenic properties of Silibinin: effect on TGF beta and matrix gene expression of hepatic stellate cells. Hepatology 22:286 A.

17. Raetsch1, J D Jia2, G Boigk1, M Bauer3, E G Hahn3, E-O Riecken1 and D Schuppan3 (2002): Pentoxifylline downregulates profibrogenic cytokines and procollagen I expression in rat secondary biliary fibrosis. Gut 50:241-247. 
18. Ward A, and Clissold SP. (1987): Pentoxifylline-A review of its pharmacodynamic and pharmacokinetic properties, and its therapeutic efficacy. Drugs 34:50-97.

19. Guerrini M, Pecchi S and Rossi C. (1983): Effects of pentoxifylline on blood hyperviscosity and peripheral hemodynamics in patients with peripheral obliterating arterial disease. Pharmacotherapeutica 3(suppl 1):52-66.

20. Peters P. A. and Warren K. S. (1969): A rapid method of infecting mice and other laboratory animals with Schistosoma mansoni by subcutaneous injection. J. Parasitol., 55-58

21. Ismail M., Metwally, A., Farghaly, A. Bruce, J. Tao, L. and Bennet, JL. (1996): Characterization of isolates of Schiostosoma mansoni from Egyptian villagers that tolerate high doses of praziquantel . Am.J. Trop. Med. Hyg., 55: 241-248.

22. Giboda, M. and Zdarska, Z, (1994): Alkaline phosphatase as a marker of Schistosoma mansoni egg viability. Folia Parasitol., (Praha), 41: 55-58.

23. Xiong, LI, Zhu JF, Luo, DD and Cai, SQ (2003): Effect of pentoxifylline on the hepatic content of TGF-B1 and collagen in schistosomiasis japonica mice with liver fibrosis. World J Gastroenterol., 9 (1): 152-154

24. Jacobs W. ,Bogers J, Deelder A, Wery, $M$ and Van Marck, $E$ (1997): Adult worms positively modulate soluble egg antigen induced inflammatory hepatic granuloma formation in vivo. Sterological analysis and immunophenotyping of extracellular matrix proteins, adhesion molecules and chemokines. Am. J. Pathol., 150: 2033-2045.

25. Rice AB, Moomaw CR, Morgan, DL and Bonner JC (1999): Specific inhibitors of plateletes derived growth factor or epidermal grpwth factor receptor; Tyrosin kinase reduce pulmonary fibrosis in rats. Am. J. Pathol., 155: 213 - 221

26. Han DC, Isono $M$, Chen $S$, Hong SW, Wolf G and Ziyadeh FN (2001): Leptin stimulates type I collagen production in ob/ob mesangial cells: glucose uptake and TGF-B type II receptor expression. Kidney Int., 59:1315-1323

27. Bataller $\mathbf{R}$ and Brenner $\mathbf{D}$ (2005): Liver fibrosis. J. Clin. Invest., 115(2): 209-218.

28. Pinzani $M$, and Marra $F$ (2001): Cytokine receptors and signaling during stellate cell activation. Semin. Liver Dis., 21:397-416.

29. Friedman SL (2000):: Molecular regulation of hepatic fibrosis: an integrated cellular response to tissue injury. J.Biol. Chem., 275:2247-2250.

30. Don CR (2005): Antifibrotic therapy in chronic liver disease Clinical Gastroenterology and Hepatology (4): .95-107

31. Geerts, A. (2001):. History, heterogeneity, developmental biology, and functions of 
quiescent hepatic stellate cells. Semin. Liver Dis.,21:311-335.

32. Wyler DJ (1992): Why does liver fibrosis occur in schistosomiasis. Parasitol. Today 8: 277-279.

33. Ebeid F A (1995): Efficacy of combination of metrifonate and praziquantel in treatment of Schistosoma mansoni infection in albino mice. Arzneimittelforschung 45: 519521

34. Giboda $M$ and Smith $J \mathbf{M}$ (1994): Schistosoma mansoni eggs as a target for praziquantel efficacy of oral application in mice. J. Trop. Med Hyg., 97: 98102

35. Preaux A M, Mallat, $A$ and Mavier P (1997): Pentoxifylline inhibits growth and collagen synthesis of cultured human hepatic myofibroblast-like cells. Hepatology 26: 315-322.

36. Reis L F, Ventura T G, Souza S $O$, Arana-Pino, $A$ and Takiya $C$ $M$ (2001): Quantitative and qualitative interferences of pentoxifylline on hepatic Schistosoma mansoni granulomas: Effects on extracellular matrix and eosinophil population. Mem. Inst. Oswaldo. Cruz., 96:107-120.

37. Berman and Duncan MR (1990): Pentoxifylline inhibits the proliferation of human fibroblasts derived from keloid, scleroderma and morphoe skin and their production of collagen, glycosaminoglycans and fibronectin. Br. J. Dermatol., 123:339-346.
38. Ramadori, G., and Saile, B. (2004):. Portal tract fibrogenesis in the liver. Lab. Invest., 84:153159.

39. Tarcin O, Avsar K, Demirturk, $L$ Baloglu $H$. and Gurbuz A (2003): In vivo inefficiency of pentoxifylline and interferonalpha on hepatic fibrosis in biliary- obstructed rats: assessment by tissue collagen content and prolidase activity. J. Gastroenterol. Hepatol., 18(4): 437-444.

40. Ikejima $\mathbf{K}$, Honda, $\mathbf{H}$, Yoshikawa $M$ and Sato, $M$ (2001): Leptin augments inflammatory and profibrogenic responses in the murine liver induced by hepatotoxic chemicals. Hepatol., 34: 288-297.

41. Leclercq I, Farrell G, Schriemer $P$, and Robertson $G$. (2000): Leptin is required for development of hepatic fibrosis. Hepatol., 32: 302

42. Aleffi S, Petrai I, Bertolani C, Parola M, Colombatto S, Novo E, Vizzutti F, Anania FA, Milani S, Rombouts K, Laffi G, Pinzani M, Marra F.(2005): Upregulation of proinflammatory and proangiogenic cytokines by leptin in human hepatic stellate cells. Hepatology 42 (6): 13391348.

43. Ikejima $K$, Okumura $K$, Lang T, Honda H, and Sato N (2005): The role of leptin in progression of non-alcoholic fatty liver disease, Hepatol. Res., 33 (2): 151-154.

44. Nakamura T, Nagasaka $S$, Kusaka I and Saito T (2001): Clinical implication of serial 
leptin measurement in subjects with type 2 diabetes mellitus. Endocr. J., 48:87-94.

45. Cao Q, Mak $K$, and Lieber $C$ (2006): Leptin enhances alpha (I) collagen gene expression in LX-2 human hepatic stellate cells through JAK-mediated $\mathrm{H}_{2} \mathrm{O}_{2-}$ dependent MAPK pathways. J. Cell. Biochem., 97 (1): 188-197.

46. Ding $X$, Saxena $K$, Lin S, Xu A, and Anania F (2006): The role of leptin and adiponectin: a novel paradigm in adipocytokine regulation of liver fibrosis and stellate cell biology. Am. J. Pathol., 166(6): 1655-1659. 


\title{
كفاءة البنتوكسيفللين كمضاد للتليف في التليف الكبدي البلهارسي
} لقئران المختبر

\author{
إيهان خليفة 1 و هبة عبد الجليل 2ّو أحمد خالد فراج³ \\ وهالة السبب حمودة 4 و أمل أحمد بعلث 4 \\ أقسام الطفيليات1 وعلم الأدوية22 و الامراض المنوطنة3 و الكيمياء الحيوية الطبية 4 \\ كلية الطب - جامعة طنطا
}

الهدف : هذه دراسة تمهيدية تهدف إلى تقييم تأثنر عقار البنتوكسفللين المحتمل كمضاد للتليف في فئران

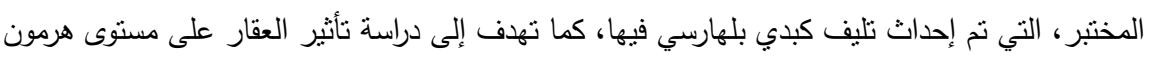
اللبتين ومعامل نقل النمو بينا (1) في المصل كآلية محتملة لمنع النليف، مع قياس مؤشرات التليف الكبدي.

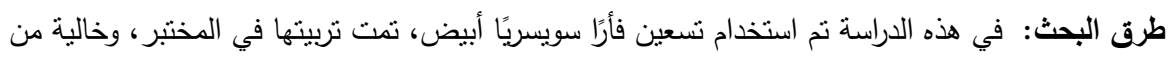

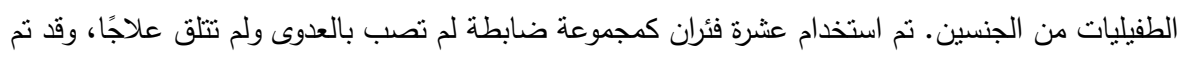

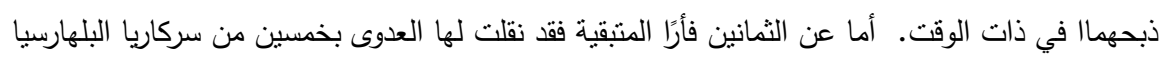
مانسوني لكل فأر ، ونم تقسيمها إلى المجموعات النالية: مجموعة 1 (مصابة ولم تعالج) ومجموعة 2 (مصابة 2 (مصابة

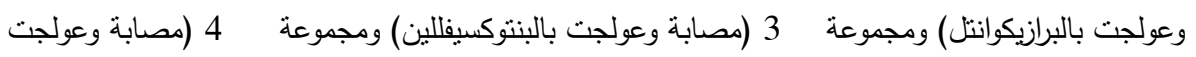
بالبنتوكسيفللين و البرازيكوانتل).

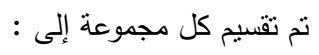
- مجموعة فرعية ( أ) التي بدأت العلاج في الأسبوع الساد من العدوى و ذ ذبحت في نهاية الأسبوع التاسع.

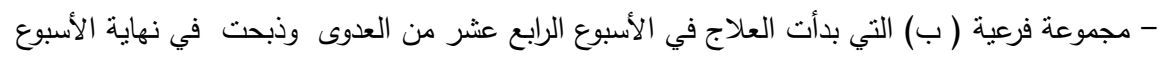

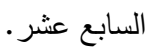
تم قياس كفاءة العلاج بالفحص النسيجي وقياس حجم الورم الحبيبي، وقياس الهيدروكسي برولين في الكبد، مع

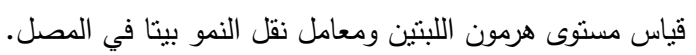
النتائج : في حالة العلاج بالبرازيكوانتل تبين وجود نقص ذي دلئل دلانة إحصائية في حجم الورم الحبيبي ومحتوى

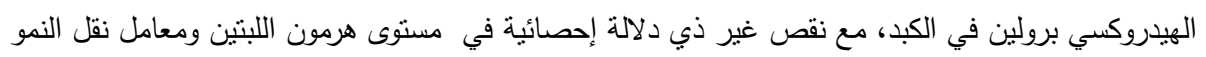

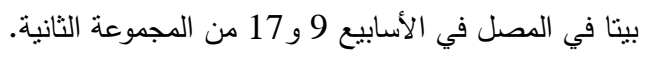
أظهر عقار البنتوكسيفللين وجود نقص ذي دلالة إحصائية في حجم الورم الحبيبي ومحتوى الهيدروكسي برولين

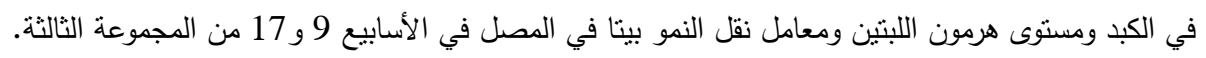


أما المجموعة الرابعة التي تلقت كلا العقارين (البنتوكسيفللين و البرازيكوانتل) فقد تبين فيها نقص ذو دلالة إحصائية أكبر فيما يتعلق بحجم الورم الحبيبي ومحتوى الهيدروكسي برولين في الكبد ومستوى هرمون اللبتين

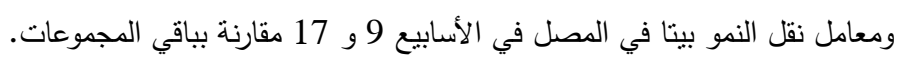

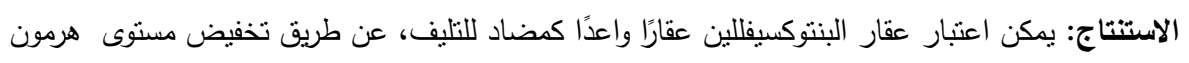

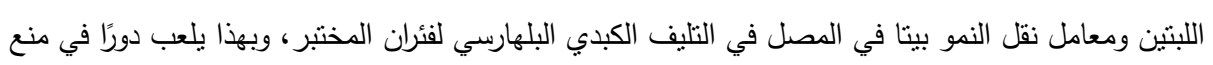
التليف، ،وأفضل نتائجه تكون عندما يتم استعماله مع عقار البرازيكوانتل. 